\title{
Determining the Relationship between Home Environment and Academic Performance. a case of Clinical Medical Rehabilitation Students of Obafemi Awolowo University
}

\author{
Article by Ilesanmi Oluwafemi Temitayo \\ Ph.D. in Public Health, Texila American University, Nigeria \\ E-mail: aboundinggrace08@yahoo.com
}

\begin{abstract}
The environment a child finds himself goes a long way in determining his learning ability and ultimately his academic performance in school. Home environment has been recognized as having a relationship with the academic achievement of students. The present research study was designed to assess the various home environment variables which are predictive of academic performance of clinical Medical Rehabilitation students in Obafemi Awolowo University $(O A U)$. The variables under consideration were the academic performance (grade point average) as a dependent variable and the parents' level of income, level of education, residential area, marital status, family structure, and students' accommodation type, average number of meals taken per day, study hour, and gender were independent variables. The data were collected from 102 clinical students who were purposively sampled from the department of Medical Rehabilitation using structured questionnaire. Data were collated and analyzed using descriptive and inferential statistics of Pearson Chi-square and multiple regression analyses. The result showed that there was statistical significant association between academic performance and father's level of income, the number of study hours per day and the average number of meals taken per day. In conclusion, this study reveals that father's level of income, number of study hours per day and average number of meals taken per day as home environment variables considered is predictive of academic performance of Clinical Medical Rehabilitation Students of OAU.
\end{abstract}

Keywords: Home environment, academic performance, clinical students

\section{Introduction}

The environment a child finds himself goes a long way in determining his learning ability and ultimately his academic performance in school (Ayodele, 2006). Home environment has been recognized as having a relationship with the academic achievement of students (Ajila and Olutola, 2007; Ichado, 1998; Nzewuawah, 1995). Studies have found that the physical environments among other factors are all variables that affect students' achievement (Molnar, et al, 2000). The factors/variables that affect student performance may be termed as student factors, family factors, school factors and peer factors (Crosnoe, Johnson and Elder, 2004; Eamon, 2005). Generally these factors include age, gender, geographical belongingness, ethnicity, Parents marital status, socio economic status (SES), Parents' education level, Parents' profession, language, income and religious affliation. Researches have shown that school environment factors, student role performances, peer factors have been shown to affect test scores (Eamon, 2005; Crosnoe et al 2004; Santor et al, 2000). Research has found that socioeconomic status (SES), parental involvement and family size are particularly important family factors (Major banks, 1996). The most important predictor of achievement in school associated with the family is socioeconomic status of parents (Munsincer, 1999; Dubey, 1972). Socio economic status can be defined as a person's overall social position to which attainments in both the social and economic domain contributes. Socioeconomic background refers to parents' educational attainment, occupation, level of income and social class placement (Jeynes, 2002; McMillan \& Western, 2002). Parental education and family socioeconomic status level have positive correlations with the student's quality of 
achievement (Jeynes, 2002; Mitchell \& Collom, 2001; Ma \& Klinger, 2000; Caldas \& Bankston, 1997; Parelius \& Parelius, 1987). While there is disagreement over how best to measure SES, most studies indicate that children from low SES families do not perform as well as they potentially could at school compared to children from high SES families (Graetz, 1995). Various studies have tried to find out the relationship between these home environment variables and the academic performance of University students in Nigeria and other parts of the world. However, there have been limited studies on which home environment variable best predict the academic performance of University students using grade point average (GPA) in Nigeria. This study is a survey which sought to determine the relationship between home environment variables and academic performance of clinical Medical Rehabilitation students in the College of Health Sciences of Obafemi Awolowo University, Ile Ife, Osun State.

\section{Significance of study}

The study will help to reveal components of home environment responsible for students' academic performance in a university in Nigeria. It will also compare the relationships of the variables of home environment as they affect the academic performance of students in university and help to determine how the variables best predicts their contribution to good academic performance. This is particularly useful for policy makers, health administrators and clinical educators in the educational planning and implementation as it offers empirical support for them. Furthermore, students would also benefit from the study through suggestions offered on the interactions of the variables to improving academic performance. The study will lay a solid foundation which subsequent researchers in similar studies may build upon.

\section{Statement of problem}

Many studies have examined the factors affecting the academic performance of graduate students which included socioeconomic status of parents, family structure amongst others. Home environment variables have been shown to contribute to the academic performance of students. Presently I am not aware of any study in Nigeria which sought to determine the relationship between home environment variables and academic performance especially among university students. This study therefore attempts to investigate parents' socioeconomic status, gender, average number of meals taken per day, hours of study, accommodation type which is home environment variables as contributory factors to students' academic performance among Clinical Medical Rehabilitation students of Obafemi Awolowo University.

\section{Research questions}

The major research questions for this study include the following:

a. What home environment variables are predictive of academic performance (using GPA) among Clinical Medical Rehabilitation Students in OAU?

b. How good are family environment variables at predicting grade point average among Clinical Medical Rehabilitation Students in OAU?

\section{Research objectives}

1. To assess the various home environment variables which are predictive of academic performance using grade point average of Clinical Medical Rehabilitation Students in OAU.

2. To determine which home environment variable best predicts academic performances using grade point average of Clinical Medical Rehabilitation Students in OAU.

\section{Hypotheses}

1. Parent's level of income would not have a significant association with the academic performance of clinical medical rehabilitation students. 
2. Parent's level of qualification would not have a significant association with the academic performance of clinical medical rehabilitation students.

3. Family structure would not have a significant association with the academic performance of clinical medical rehabilitation students.

4. Gender would not have a significant association with the academic performance of clinical medical rehabilitation students.

5. The average number of meals taken per day would not have a significant association with the academic performance of clinical medical rehabilitation students.

6. Type of accommodation of students would not have a significant association with the academic performance of clinical medical rehabilitation students.

7. Parents' residential area would not have a significant association with the academic performance of clinical medical rehabilitation students.

8. Number of hours of study would not have a significant association with the academic performance of clinical medical rehabilitation students.

9. Parents' marital status would not have a significant association with the academic performance of clinical medical rehabilitation students.

\section{Literature review}

Educational performance of school has also been found to vary according to the student's sex (Horne, 2000). Reviews of the evidence suggest that boys suffer an educational disadvantage relative to girls, especially in terms of performance in literacy (Buckingham, 2000b, 1999 Chambers and Schreiber, 2004). Still other researches have found little to no difference in achievement between the sexes (Chamber and Schreiber, 2004; Eitle, 2005).

Nutrition is closely linked to overall physical health and is a correlate of academic performance (Hoffman, et al, 2010). Socioeconomic status is significantly correlated with both academic performance and obesity (Baxter et al, 2011). Gender, ethnicity, and father's occupation are significant contributors to student achievement (McCoy, 2005; Peng and Hall, 1995). Krashen (2005) concluded that students whose parents are educated score higher on standardized tests than those who parents were not educated. The academic performance of students heavily depends up on the parental involvement in their academic activities to attain the higher level of quality in academic success (Bernard, 2004; Shumox and Lomax, 2001; Henderson, 1988). Family structure has also been noted to contribute to academic performance of students. Children from families of single parent (sole parent are likely to have lower educational performance (Rich, 2000). Students from non-metropolitan area are more likely to have lower educational outcomes in terms of academic performance and retention rates than students from metropolitan area (HREOC, 2000; Cheers, 1990). Lower educational attainment has also been found to be associated with children living in public housing compared to those in private housing (Sparkes, 1999). A number of studies have found that a child's home environment account for a substantial portion of the effects of family income on cognitive outcomes in young children (Duncan and Brooks-Gunn, 1997). Studies have also shown that school effort in an indicator of academic performance (Ceballo et al, 2004; Carbonaro, 2005). School effort has been defined as the amount of time and energy that student expend in meeting the formal academic requirements established by their teacher and/or school. High student effort leads to greater educational values, which in turn indirectly affects student performance. This has been linked to higher student grade point average (GPA) (Carbonaro, 2005). GPA refers to a ccumulative grade point average a student earns for all university courses. Research proves that university or even high school GPA predicts a student's academic performance (Mckenzie and Schweitzer, 2010).

Shoukat et al, 2013 considered gender, age, teaching, faculty, students schooling, residential area of students, medium of instructions in schools, tuition trend, daily study hour and accommodation as hostelries or day scholar as factors which affect the students academic gain and learning performance. Kanyongo et al, 2006 in their study considered possession of such things lie piped water, electricity, refrigerator and television which collectively taken to 
be a measure of socioeconomic status. SES, together with several other factors were used as measures of the students' home environment in their study. Ajila and Olutola (2000) investigated Parents' socioeconomic status on University students' academic performance. The study revealed that family income, occupations, house type, level of Parents' education and dwelling area exert a significant influence on academic achievement. Kingdom (1996) reported that home factors have significant correlation with students' academic achievement. He argued that student's age and number of hours of home study per week affect academic achievement. He also identified family economic status as being significantly related to academic achievement. Chadwick et al, 1976 conducted a study on Indian education in the city and found that family instability is significantly related to GPA for females and not for males.

Academic success is an excellent indicator for the overall well being of youth and a primary predictor and determinant of adult health outcomes (Strabstein and Piazza, 2008). Variation in the social economic background remains one of the major sources of educational inequality. Policy makers and researchers have sought to find out which factor(s) really contribute to the academic performance of higher institution students so as to know how to direct policies that will meditate these factors and hence proffer an influence which will yield a good outcome for then as a good academic performance has a positive correlation to their future achievement.

\section{Methods}

\section{Study area and population}

This study was carried out in the department of medical rehabilitation, faculty of Basic Medical Sciences, College of Health Sciences of ObafemiAwolowo University, Ile-Ife, Osun State, Nigeria. Clinical students (Clinical 1 and 2) of the department of medical rehabilitation (comprising of Physiotherapy and Occupational therapy) were the study population.

\section{Research design}

The research design employed for the study is ex-post facto using a survey design and a multiple regression design. Asika (1991) stated that ex-post facto research is a systematic empirical study in which the researcher does not in any way control and manipulate the independent variables because the situation for the study already exists or has already taken place. The author further opined that the researcher could not manipulate the independent variables because they cannot be manipulated. However, the researcher can indeed create or contrive a situation that will generate the requisite data for analysis. In this study, the home environment factors are located from factors studied in the education literature.

\section{Data collection}

Information was collected from respondents by means of a pre-tested 20- item, purpose designed, self- administered anonymous questionnaire containing open and closed ended questions. The questionnaire was divided into four major sections for ease of administration. The instruments are structured questionnaire aimed at eliciting the respondents' view about the relationship between home environment variables and their academic performance.

Section one of the questionnaire contained 6 items which sought for information on demographic data such as gender, age, religion, course option, course level and ethnic group.

Section two of the questionnaire contained 4 items which required the respondents to supply information on their present cumulative grade point average, type of residential accommodation they use, the number of personal study hour(s) per day and the average number of meals taken per day. Section three of the questionnaire contained 5 items which required the respondents to supply information on their Parents' level of income per month, Parents' educational attainment, family structure, Parents' residential area and Parents' marital status. Section four of the questionnaire contained 5 items which are close and open ended questions which sought to find out students response on factors may affect their academic 
performance which include interest in the course of study, peer influences, perception of the course of study and parents' support.

\section{Sample Size determination}

The minimum sample size was calculated using Yamane (1967) using the equation

$$
\mathrm{n}=\frac{\mathrm{N}}{1+\mathrm{N}(\mathrm{e})^{2}}
$$

where $\mathrm{n}$ is the sample size, $\mathrm{N}$ is the population size which is 121 clinical medical rehabilitation students and e is the level of precision at $\pm 5 \%$ (A 95\% confidence level and $\mathrm{P}=0.5$ are assumed for the equation). Therefore $\mathrm{n}=93$. To give allowance for an anticipated non-response rate of $10 \%$ ( 9 respondents), the sample size was increased by 9 to make 102 respondents. A total of 121 questionnaires were then taken to the students to be distributed for the study. 102 (response rate of 84\%) were returned and used for the analysis. Each respondent was provided with an assurance of confidentiality of information he or she provides in the questionnaire.

\section{Sampling method}

A purposive sampling method was used to select clinical students from the department of Medical rehabilitation comprising both Physiotherapy and Occupational therapy. They are students who are in their 400 and 500 levels and had spent sufficient time in the course to accumulate a substantive grade point average which will be of relevance to present study and this could now be generalized to larger population of students in future studies.

\section{Data analysis}

The data gathered through the completed questionnaires were collated, analyzed and presented using both descriptive and inferential statistics. Inferential statistics used was multiple regression analysis and Pearson Chi-square analysis. In this study a linear model of clinical student performance was designed. The students cumulative grade point average (CGPA), which constitutes the dependent variable was got from the questionnaire where it was imputed as high performance ( $>60 \%$ ) and low performance (between 50 and $59 \%$ ) and father's income, mother's income, father's education, mother's education, family structure, average number of meals taken per day, student accommodation type, parents' residential area, study hour, gender and parents marital status as independent variables. All clinical medical rehabilitation students in OAU the sample consist of $(\mathrm{n}=102)$. Close ended questions were used in part one to three while part 4 constituted both closed and open ended questions to elicit response of respondents on questions which have been established in other literatures as contribution to students academic performance. Data from questionnaire was complied, sorted, edited, classified and coded into the coding sheet of SPSS 13.0 (version) and Microsoft Excel 2007.

\section{Results}

\section{Demographic characteristics of the study population}

The profile of 102 respondents interviewed with the questionnaire is shown in Table 1 . The clinical students who participated in the survey had more males than females $(62.7 \%$ males and $37.3 \%$ females). The sex distribution is shown in figure 1 . The mean age was 22.9 years with most of respondents (75\%) in the 20-24years age bracket. These were followed by those aged 25-29years (23.4\%). Majority of the students who participated in the study were in clinical 1(51.6\%), Physiotherapy option (87.5\%), Christians (79.7\%) and mostly Yoruba tribes $(93.8 \%)$.

\section{Association between student academic performance and home environment}


Texila International Journal of Public Health

Volume 4, Issue 4, Dec 2016

\section{variables}

Research question 1 was answered using tables $2-13$ to know which home environment variables are predictive of academic performance using GPA among clinical medical rehabilitation students in OAU.

Table 2-13 are Chi-square analyses which show associations between student academic performance and father's income, mother's income, father's education, mother's education, family structure, gender, average number of meals taken per day, student type of accommodation, parents residence, study hours, parents marital status (parents together), Parents marital status (parents together).

Table 2, Table 8 and Table 11 showed there were statistical significant association between academic performance and father's income, average number of meals taken per day and study hours per day..

Table $3,4,5,6,7,9,10,12$, and 13 showed there was no statistical significant association between student academic performance and mother's income father's education, mother's education, family structure, gender, student type of accommodation, parent's residence, marital status (parents divorced), marital status (parents together).

\section{Predicting relationship between student academic performance and home environment variables}

Research question 2 was answered using table 14. It is a regression statistics for independent and dependent variables. In the summary, academic performance using CGPA was used as dependent variable and the father's income, mother's income, father's education, mother's education family structure, number of meals taken per day, student accommodation type, parent's residential area, study hour, gender and parent's marital status (parent divorced, parents together) as independent variables. The result showed that $\mathrm{R}^{2}=12.6 \%$. This shows that $12.6 \%$ variations in academic performance are due to the independent variables considered. The coefficients of fathers' income, mothers' income, mothers' education, family structure, average number of meal taken per day, study hour, parents' residence, gender, parents divorced and parents together show that a unit increase in academic performance by 0.37 , $0.05,0.17,0.18,0.66,0.37,0.44,0.09,0.54,0.53$ respectively, holding other factors as constant. The coefficients are insignificant at $5 \%$ level of significance. Also, the coefficients of fathers' education and student accommodation type show that a unit increases in these variables cause of decrease in academic performance by -0.25 and -0.11 , holding other factors as constant. The coefficients are also insignificant at $5 \%$ level of significance.

\section{Discussion}

This study was conducted to carry out a survey to determine the relationship between home environment variables and academic performance of clinical medical rehabilitation students of ObafemiAwolowo University in Ile-Ife, Osun State, Nigeria. Studies on home environment variables and academic performance have been of special interest because of the significant impact it has on the health and well being of the students. The sex distribution in this study had more male respondents than female respondents. This result is similar to a study carried out in 2013 which also reported male respondents higher in number than female respondents (Ali Shoukat et al, 2013). The result also showed higher Christians respondents and Yoruba respondents than any other religious and tribes respectively. This result can be explained by the fact that the sampled University is predominantly a Christian institution situated in Yoruba land. By that it means that the study environment will usually reflect the characteristics of the study population.

Father's level of income, average number of meals taken per day and the number of hours of study had a significant association with the academic performance of the students. This result corroborated the studies by Abdu-raheem, 2015; Lacour and Tissington, 2011l Ali, Shoukat et al, 2013 which showed a significant relationship between father's level of income and academic performance. However, the study by Hijazi and Naqvi, 2006 corroborated the 
result that parent level of income has a significant relationship with academic performance with deference to mother's level of income which the result of this study did not show.

Credence to this result Pollit (1984), observed that good nutrition is an endogenous factor that affects learning ability and skill before and after the child is in school. Also, Acham et al, 2012 found a significant association between consumption of breakfast and a midday meal with academic achievement of students in Uganda. Also in credence to this result, Ali et al (2013) found that study hours significantly affect the academic performance of students of Islamia University, Pakistan. Also, Hijazi et al (2006) found that the number of hours spent in study after colleges on daily basis significantly affect academic performance of students of Punjab University of Pakistan. These home environment variables of father's level of income, average number of meals taken per day and number of hours of study by the students significantly predict academic performance in this study. Other home environment variables considered such as parents' level of education, family structure, parents' residential area, and parents' marital status did not significantly predict association between them and academic performance in this study. This may not mean that these home environment variables would not predict a significant association with academic performance in other climes and settings as some studies have showed a significant association (Shoukat Ali et al, 2013; Adeyemi and Adeyemi, 2014; Abdu-raheem, 2015, Hijazi and Naqvi, 2006; Asikhia, 2010).

Overall, the contribution of home environment factors considered in this study was about 13 percent of the variance in academic performance. This means that home environment factors account for a little bit greater than tenth of the variance in the academic performance. This shows that there are other variables which are not considered in this study which account for the other measure of variance in academic performance.

\section{Conclusion}

The outcome of this study reveals that father's level of income, average number of meals taken per day and the number of hours of study as home environment variables considered which are predictive of academic performance of clinical medical rehabilitation students of ObafemiAwolowo University, Ile-Ife.

\section{Recommendations}

Based on the findings in this study, the following are therefore recommended:

1. Because this study is only for the clinical medical rehabilitation students of ObafemiAwolowo University, Ile-Ife, it will be advisable that the study should be conducted at a wide level of the whole University or to other Universities so that the results may be externally valid.

2. Policies that will improve the level of employment opportunities for the parents should be encouraged by government as these will affect the level of income of parents and guardians which will otherwise affect the academic performance of students.

3. Public health campaigns should be facilitated to families to enlighten them about the significance of improving the nutrition status of their children which is a key factor in improving health and academic performance of their children.

4. Conducive environment for reading should be made available for the students by the authorities as good number of hours will be required to assimilate the volume of academic materials required for their learning. 
Table 1. Demographic characteristics of respondents by Gender Variables

\begin{tabular}{|c|c|c|c|c|c|c|}
\hline & $\begin{array}{l}\text { Males } \\
\mathrm{N}\end{array}$ & $\begin{array}{l}(64 ; 62.7 \%) \\
(\%)\end{array}$ & $\begin{array}{l}\text { Females } \\
\mathrm{N}\end{array}$ & $\begin{array}{l}(38,37.3 \%) \\
\%\end{array}$ & $\begin{array}{l}\text { Total } \\
\mathrm{N}\end{array}$ & $\begin{array}{l}(102 ; 100 \%) \\
\%\end{array}$ \\
\hline $\begin{array}{l}\text { Age } \\
20-24 \\
25-29 \\
\geq 30 \\
\end{array}$ & $\begin{array}{l}48 \\
15 \\
1 \\
\end{array}$ & $\begin{array}{l}(750) \\
(23.4) \\
(1.6) \\
\end{array}$ & $\begin{array}{l}35 \\
3 \\
- \\
\end{array}$ & $\begin{array}{l}(92.1) \\
(7.9) \\
- \\
\end{array}$ & $\begin{array}{l}83 \\
18 \\
1 \\
\end{array}$ & $\begin{array}{l}(81.4) \\
(17.6) \\
(1.0)\end{array}$ \\
\hline $\begin{array}{l}\text { Course level } \\
\text { Clinical I } \\
\text { Clinical } 2 \\
\end{array}$ & $\begin{array}{l}33 \\
31 \\
\end{array}$ & $\begin{array}{l}(51.6) \\
(48.4)\end{array}$ & $\begin{array}{l}21 \\
17\end{array}$ & $\begin{array}{l}(55.3) \\
(44.7)\end{array}$ & $\begin{array}{l}54 \\
48 \\
\end{array}$ & $\begin{array}{l}(52.9) \\
(47.1)\end{array}$ \\
\hline $\begin{array}{l}\text { Course option } \\
\text { Physiotherapy } \\
\text { Occupation } \\
\text { Therapy }\end{array}$ & $\begin{array}{l}56 \\
8\end{array}$ & $\begin{array}{l}(87.5) \\
(12.5)\end{array}$ & $\begin{array}{l}28 \\
10\end{array}$ & $\begin{array}{l}(73.7) \\
(26.3)\end{array}$ & $\begin{array}{l}84 \\
18\end{array}$ & $\begin{array}{l}(82.4) \\
(17.6)\end{array}$ \\
\hline $\begin{array}{l}\text { Ethnic group } \\
\text { Yoruba } \\
\text { Igbo } \\
\text { Hausa } \\
\text { Others }\end{array}$ & $\begin{array}{l}60 \\
2 \\
- \\
2 \\
\end{array}$ & $\begin{array}{l}(93.8) \\
(3.1) \\
- \\
(3.1) \\
\end{array}$ & $\begin{array}{l}33 \\
3 \\
- \\
2 \\
\end{array}$ & $\begin{array}{l}(86.8) \\
(77.9) \\
- \\
(5.3) \\
\end{array}$ & $\begin{array}{l}93 \\
5 \\
- \\
4 \\
\end{array}$ & $\begin{array}{l}(91.2) \\
(4.9) \\
- \\
(3.9) \\
\end{array}$ \\
\hline $\begin{array}{l}\text { Religion } \\
\text { Christianity } \\
\text { Islam }\end{array}$ & $\begin{array}{l}51 \\
13 \\
\end{array}$ & $\begin{array}{l}(79.7) \\
(20.3)\end{array}$ & $\begin{array}{l}32 \\
6\end{array}$ & $\begin{array}{l}(84.2) \\
(15.8)\end{array}$ & $\begin{array}{l}83 \\
19 \\
\end{array}$ & $\begin{array}{l}(81.4) \\
(18.6)\end{array}$ \\
\hline
\end{tabular}

Table 2. Student academic performance and father's income

Father's Income

\begin{tabular}{|c|c|c|c|c|c|c|c|c|}
\hline Performance & $10-20 T$ & $20-50 T$ & $50-100 \mathrm{~T}$ & $\begin{array}{l}100- \\
200 T\end{array}$ & $>200 \mathrm{~T}$ & $\begin{array}{l}\text { Pearson } \\
X^{2} \\
\end{array}$ & Df & Sig \\
\hline $\begin{array}{l}\text { Low } \\
\text { performance }\end{array}$ & 13 & 13 & 9 & 15 & 12 & \multirow[t]{2}{*}{9.776} & \multirow[t]{2}{*}{4} & \multirow[t]{2}{*}{0.044} \\
\hline $\begin{array}{l}\text { High } \\
\text { performance }\end{array}$ & 3 & 4 & 8 & 8 & 17 & & & \\
\hline
\end{tabular}

where $\mathrm{T}$ - Thousand naira

Table 3. Student academic performance and mother's income

Mother's Income

\begin{tabular}{|l|l|l|l|l|l|l|l|l|}
\hline Performance & $\mathbf{1 0 - 2 0 T}$ & $\begin{array}{l}\mathbf{2 6 -} \\
\mathbf{5 0 T}\end{array}$ & $\mathbf{5 0 - 1 0 0 T}$ & $\begin{array}{l}\mathbf{1 0 0 -} \\
\mathbf{2 0 0 T}\end{array}$ & $\mathbf{2 0 0 T}$ & $\begin{array}{l}\text { Pearson } \\
\mathbf{X}^{\mathbf{2}}\end{array}$ & Df & Sig \\
\hline $\begin{array}{l}\text { Low } \\
\text { performance }\end{array}$ & 16 & 12 & 12 & 16 & 6 & 4.824 & 4 & 0.306 \\
\cline { 1 - 5 } $\begin{array}{l}\text { High } \\
\text { performance }\end{array}$ & 4 & 7 & 9 & 16 & 4 & & \\
\hline
\end{tabular}

where $\mathrm{T}$ - Thousand naira

Table 4. Student academic performance and father's education

Father's Education Level

\begin{tabular}{|l|l|l|l|l|l|l|l|}
\hline Performance & $\leq$ Sec & Dipl & B.Sc & $\mathbf{Z M . S c}$ & $\begin{array}{l}\text { Pearson } \\
\mathbf{X}^{\mathbf{2}}\end{array}$ & Df & Sig \\
\hline Low performance & 10 & 8 & 24 & 20 & 0.597 & 3 & 0.897 \\
\hline High performance & 5 & 4 & 16 & 15 & & & \\
\hline
\end{tabular}

Sec- secondary school, Dipl- diploma, B.Sc- Bachelor, M.Sc- Master

Table 5. Student academic performance and mother's education 


\begin{tabular}{|l|l|l|l|l|l|l|l|}
\hline \multicolumn{10}{|c|}{ Mother's Education Level } \\
\cline { 1 - 5 } Performance & $\leq$ Sec & Dipl & B.Sc & $\mathbf{M}$.Sc & $\begin{array}{l}\text { Pearson } \\
\mathbf{X}^{\mathbf{2}}\end{array}$ & Df & Sig \\
\hline Low performance & 14 & 21 & 20 & 7 & 2.024 & 3 & 0.567 \\
\hline High performance & 7 & 10 & 18 & 5 & & & \\
\hline
\end{tabular}

Sec- secondary school, Dipl- diploma, B.Sc- Bachelor, M.Sc- Master

Table 6. Student academic performance and family structure

Family Structure Sponsor

\begin{tabular}{|l|l|l|l|l|l|}
\hline Performance & One Parent & Two Parents & $\begin{array}{l}\text { Pearson } \\
\mathbf{X}^{\mathbf{2}}\end{array}$ & Df & Sig \\
\hline Low performance & 19 & 43 & 0.810 & 1 & 0.368 \\
\cline { 1 - 4 } High performance & 9 & 31 & & & \\
\hline
\end{tabular}

Table 7. Student academic performance and gender

\begin{tabular}{|l|l|l|l|l|l|}
\hline Performance & Male & Female & $\begin{array}{l}\text { Pearson } \\
\mathbf{X}^{\mathbf{2}}\end{array}$ & Df & Sig \\
\hline Low performance & 39 & 23 & 0.046 & 1 & 0.830 \\
\hline High performance & 25 & 15 & & & \\
\hline
\end{tabular}

Table 8. Student academic performance and average number of meals taken per day

\begin{tabular}{|l|l|l|l|l|l|l|}
\hline Performance & $\mathbf{1}$ meal & $\mathbf{2}$ meals & $\mathbf{3}$ meals & $\begin{array}{l}\text { Pearson } \\
\mathbf{X}^{\mathbf{2}}\end{array}$ & Df & Sig \\
\cline { 1 - 5 } Low performance & 7 & 43 & 12 & 5.689 & 2 & 0.049 \\
\hline High performance & 0 & 28 & 12 & & & \\
\hline
\end{tabular}

Table 9. Student academic performance and performance and student type of accommodation

Accommodation Type

\begin{tabular}{|l|l|l|l|l|l|}
\hline Performance & Hostel & $\begin{array}{l}\text { Private } \\
\text { accommodation }\end{array}$ & $\begin{array}{l}\text { Pearson } \\
\mathbf{X}^{\mathbf{2}}\end{array}$ & df & Sig \\
\cline { 1 - 3 } Low performance & 38 & 24 & 0.015 & 1 & 0.902 \\
\cline { 1 - 3 } High performance & 25 & 15 & & \\
\hline
\end{tabular}

Table 10. Student academic performance and parents’ residence.

Parents Residence

\begin{tabular}{|l|l|l|l|l|l|}
\hline Performance & Rural & Urban & $\begin{array}{l}\text { Pearson } \\
\mathbf{X}^{\mathbf{2}}\end{array}$ & df & Sig \\
\hline Low performance & 14 & 48 & 2.648 & 1 & 0.104 \\
\cline { 1 - 3 } High performance & 4 & 36 & & & \\
\hline
\end{tabular}

Table 11. Student academic performance and study hours per day

Study hours

\begin{tabular}{|l|l|l|l|l|l|l|}
\hline Performance & $<\mathbf{2 h r s}$ & $\mathbf{2 - 5 h \mathbf { h }}$ & $\mathbf{>}$ hhrs & $\begin{array}{l}\text { Pearson } \\
\mathbf{X}^{\mathbf{2}}\end{array}$ & $\mathbf{d f}$ & Sig \\
\hline Low performance & 7 & 43 & 12 & 5.689 & 2 & 0.049 \\
\hline High performance & 0 & 28 & 12 & & & \\
\hline
\end{tabular}

Table 12 Student academic performance and parents marital status (parents divorced) 
Texila International Journal of Public Health

Volume 4, Issue 4, Dec 2016

Parents Divorced

\begin{tabular}{|l|l|l|l|l|l|}
\hline Performance & Yes & No & $\begin{array}{l}\text { Pearson } \\
\mathbf{X}^{\mathbf{2}}\end{array}$ & Df & Sig \\
\hline Low performance & 4 & 58 & 0.093 & 1 & 0.761 \\
High performance & 2 & 38 & & & \\
\hline
\end{tabular}

Table 13. Student academic performance and parents marital status (parents together)

Parent's together

\begin{tabular}{|l|l|l|l|l|l|}
\hline Performance & Yes & No & $\begin{array}{l}\text { Pearson } \\
\mathbf{X}^{2}\end{array}$ & Df & Sig \\
\hline Low performance & 54 & 8 & 0.004 & 1 & 0.925 \\
\cline { 1 - 3 } Higerformance & 35 & 5 & & & \\
\hline
\end{tabular}

Table 14. Regression statistics for independent and dependent variables

\begin{tabular}{|l|l|l|l|l|}
\hline & & Coefficient & Standard Error & Significant (P-value) \\
\hline Performance & FINCOM & 0.372 & 0.228 & 0.103 \\
\hline & MICOME & 0.051 & 0.249 & 0.837 \\
\hline & FEDUC & -0.250 & 0.284 & 0.380 \\
\hline & MEDUC & 0.177 & 0.318 & 0.578 \\
\hline & FSTRUC & 0.184 & 0.561 & 0.743 \\
\hline & MEAL & 0.659 & 0.485 & 0.174 \\
\hline & STUDYHR & 0.373 & 0.426 & 0.381 \\
\hline & STUACCOM & -0.114 & 0.484 & 0.814 \\
\hline & PRESIDENCE & 0.442 & 0.723 & 0.541 \\
\hline & GENDER & 0.088 & 0.473 & 0.853 \\
\hline & PRROVRCED & 0.541 & 1.249 & 0.665 \\
\hline & PTOGETHER & 0.531 & 0.877 & 0.545 \\
\hline & CONSTANT & -6.347 & $3 / 539$ & 0.073 \\
\hline
\end{tabular}

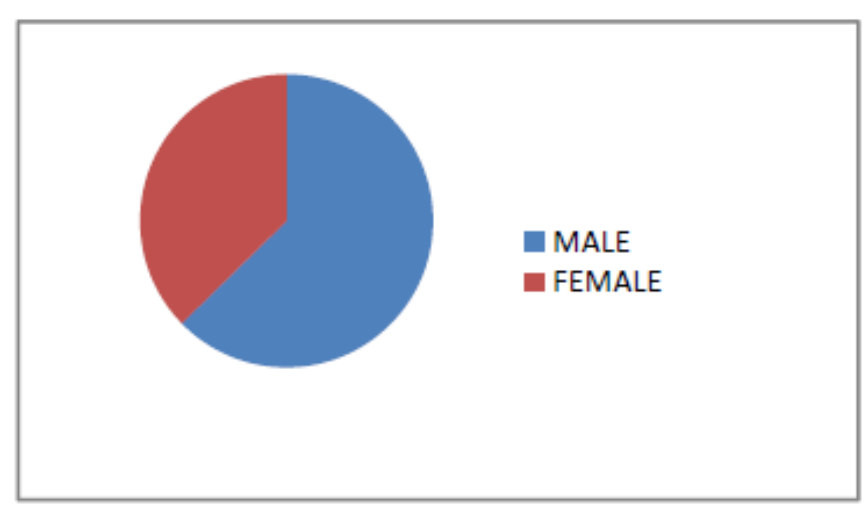

Figure 1. Gender distribution of respondents

\section{References}

[1]. Abdul-raheem B. O (2015). Parents' Socio-economic status as predictor of secondary school students` Academic performance in Ekiti State, Nigeria. Journal of Education and practice. Vol 6. No.1, 2015. ISSN 2222-1735.

[2]. Adeyemi A.M and Adeyemi S.B (2014). Personal factors as predictors of Students' academic achievement in Colleges of Education in South Western Nigeria. Education Research and Reviews. Vol (4). Pp 97-109. 
[3]. Ajila, C and Olutola, A. (2000). Impact of parent's socioeconomic status on University Student's academic performance: Ife Journal of Educational Studies 7(1), 31-39

[4]. Asika, N (1991). Research methodology in the behavioural sciences. Lagos. Longman Nigeria Plc. [5]. Asikhia, O.A (2010). Students and teacher's perception of the causes of poor academic performance in Ogun State Secondary Schools, Nigeria. Implication for counseling for National Development. European Journal of Social Sciences. 13 (2): 229-249.

[6]. Ayodele S.O. (2006). Educational Opportunities for Nigeria learner, how to we fore thus far? A paper presented at the workshop organized by Network for Gender Sensitive Educational Management in Africa and the British Consul in Nigeria.

[7]. Barnard, W. M. (2004). Parent involvement in elementary school and educational attainment. Children and Youth Services Review, 26, 39-62.

[8]. Baxter, S.D., Royer J.A., Hardin, J.W, Guinn, G.H, and Devlin, C.M. (2011). The relationship of school absenteeism with body mass index, academic achievement and socioeconomic status among fourth-grade children. Journal of School Health, 81, 417-423.

[9]. Bratti, M. and Staffolani S (2002). Student Time Allocation and Educational Production Functions. University of Ancona Department of Economics working Paper No. 170

[10]. Buckingham, J (1999). The puzzle of boys' educational decline: a review of the evidence. Issue analysis, No. 9, Centre for Independents studies, Sydney.

[11]. Buckingham, J. (2000b). Boy troubles: understanding rising suicide, rising crime and educational failure, CIS policy monograph 46, Centre for Independent studies, Sydney.

[12]. Caldas, S.J., \&Bankston C.L. (1997). The effects of school population socioeconomic status on individual student academic achievement. Journal of Educational Research, 90; 267-277.

[13]. Chadwick, Bahr and Stauss (1976). India education in the city: Correlates of academic performance. J. Educa. Res. 70(2): 11-12

[14]. Chambers, E.A. \& Schreiber, J.B. (2004). Girls' academic achievement: Varying associations of extracurricular activities. Gender and Education, 16(3), 327-346

[15]. Cheers, B. (1990). Rural disadvantage in Australia. Australian Social Work, 43(1), 5-13.

[16]. Considine, G. and G. Zappala (2002). Factors influencing the educational performance of students from disadvantaged backgrounds, in T.Eardley and B. Bradbury, Eds,Competing Visions: Refereed proceedings of the National Social Policy Conference 2001, SPRC Report 1/52, social policy Research Centre, University of New South Wales, Sydney 91-107.

[17]. Council of Chief State School Officers. Policy Statement on School Health; 2004

[18]. Crosnoe, R., Johnson, M.K., Elder, G.H (2004). School size and the interpersonal side of education: An examination of race/ethnicity and organizational context. Social Science Quarterly, 88(5), 1259-1274

[19]. Duncan, G.J., and Brooks-Gunn, J. (Eds.) (1997). Consequences of Growing up poor. New York: Rusell Sage Foundation.

[20]. Dunkle MC, Nash MA. Beyond the Health Room. Washington DC: Council of Chief State School Officers, Resource Centre on Educational Equity; 1991

[21]. Durden, G.C. and Ellis, L.V (1995). The effect of attendance on student learning in principles of Economics, American Economic Review 85, 343-346

[22]. Escarce, J.J. (2003). Socioeconomic status and the fates of adolescent. Retrieved on September 27, 2007 from http://www.pubmedcentral.nih/gov article render.fcgi?artid

[23]. Fraser, E. (1985) School and home. London: University of London Press

[24]. Graet Z, B. (1995). Socio-economic status and school Education. DEET/ACER Canberra.

[25]. Hedwig, A., Kikefunda, J., Malda, M., Oldewage- Theron, W. H and Egal Abdukadir, A (2012). Breakfast, midday meals and academic achievement in rural primary schools in Uganda: implications for education and school health policy. Food and Nutrition Research 2012: 56: 10: 3402/frn.v56 to. 11217.

[26]. Health, S.B (1990). The wider society and education. Boston Allyn and Bacon Inc.

[27]. Henderson, A.T. (1988). Good news: An ecologically balanced approach to academic improvement. Educational Horizons, 66(2), 60-67. 
Texila International Journal of Public Health

Volume 4, Issue 4, Dec 2016

[28]. Hijazi S. T., RazaNaqvi, S. M. M (2006). Factors affecting Students' Performance. A case of private colleges. Bangladesh e- journal of Sociology. Volume 3 Number l. January 2006.

[29]. Hoffman, J.A., Franko D.L. Thompson, D.R, Stallins, V.A. and Power T.J (2010). Longitudinal behavioral effects of a school-based fruit and vegetable promotion program. Journal of Pediatric Psychology, 35, 61-71. DOI: (0.1093/jpepsy/jop041)

[30]. Horne, R. (2000). The performance of males and females in school and tertiary education, Australian Quarterly, 72 (5/6) 21-26.

[31]. Human Rights and Equal Opportunities Commission (2000). Emerging Themes: National Inquiry into Rural and Remote Education, HREOC, Sydney.

[32]. Ichado, S.M. (1998). Impact of Broken Home on Academic Performance of Secondary School Students in English Language. Journal of Research in Counselling Psychology 4(1) 84-87

[33]. Jeynes, W.H. (2002). Examining the effects of parental absence on the academic achievement of adolescents. The challenge of controlling for family income. Journal of Family and EconomicIssues, 23(2), 56-65

[34]. Kanyongo, G.Y, Certo J and Launcelot, B.I (2006). Using regression analysis to establish the relationship between home environment and reading achievement: A case of Zimbabwe. International Education Journal, 7(5), 632-641. ISSN 1443-1475 (O2006 Shannon Research Press.

[35]. Kingdom (1996). The quality and Efficiency of Public and Private Schools. A case study of Urban India. Oxford Ball. Econ. Statist. 58 (1): 55- 80.

[36]. Krashen S. (2005). The hardwork hypothesis: Is doing your homework enough to overcome the effects of poverty? Multicultural Education, 12( ), 16-19.

[37]. Lacour, M, and Tissington L.D. (2011). The effects of poverty on academic achievement. Journal of Educational Research and Review. 6 (7): 522-527.

[38]. Ma, X., \& Klinger, D.A. (2000). Hierarchical linear modeling of student and school effects on academic achievement. Canadian Journal of Education, 25(1), 41-55.

[39]. Majoribanks, Kevin. (1996). Family learning environments and students' outcomes: a Review Journal of Comparative Family Studies 27(2), 373-394

[40]. McCoy, L.P. (2005). Effect of demographic and personal variables on achievement in eight grade algebra. Journal of Educational Research, 98(3), 131-135

[41]. Mckenzie K, Schweitzer R (2010). Who succeeds at University? Factors predicting academic performance in first year Australian University students. Higher Education Research and Development. 20 (1): 21-33.

[42]. Mitchell, D.E, \& Collom, E. (2001). The determinant of student achievement at the academy for Academic Excellence. CA; school Education. University of California

[43]. Munsincer, H (1999). Fundamentals of Child Development. New York: Harcourt Brace Jovanrich Inc.

[44]. National School Boards Association. Beliefs and Policies of the National School Boards Association. Alexandria, VA: National School Boards Association; 2009

[45]. Nzewuawah, P.N. (1995). The effects of single-parenthood on the Academic performance of Students. Unpublished M.Ed Project University of Lagos

[46]. Parelius, R. J. \&Parelius, A. N (1987). Sociology of education. USA: Prentice Hall International

[47]. Peng, S. S, \& Hall, S.T. (1995). Understanding racial-ethnic differences in secondary school science and mathematics achievement (NCES No 95710). Washington DC: U.S. Department of Education

[48]. Pollit, Ernesto. 1984. Nutrition and Academic Achievement. Paris, France: UNESCO.

[49]. Rich, A. (2000). Beyond the classroom: How parents influence their children's Education, CIS Policy, monograph 48, Centre for Independent studies, Sydney.

[50]. Roberts, G.A (2007). The effect of extracurricular activity participation in the relationship between parent involvement and academic performance in a sample of third grade children Retrieved from https://www.lib.utexas.edu/etd/d/2007/robertsg 1118/Robertsg11186.pdf

[51]. Shoukat, A., Haider, Z., Khan, H., Ahmed, A (2013). Factors contributing to the Students Academic Performance. A case study of Islamia University Sub-campus. American Journal of Educational Research. 1(8):283-289, doi: 10. 12691/education 1-8-3. 
[52]. Scale, E.C., and Rochikepartain, E.C (2003) Boosting students Achievement. New Research on the power of Development Assets. Search Institute Insights Evidence 1(1), 1-10

[53]. Shonkoff, J.P. and D.A. Philips, eds, (2000), from Neurons to Neighborhoods: The Science of Early Childhood Development, National Academy Press, Washington DC.

[54]. Shumox, L. \& Lomax R(2001). Parental efficacy: predictor of parenting behaviour and adolescent outcomes. Parenting, 2(2). 127-150

[55]. Sparkes, J. (1999), Schools, Education and Social Exclusion, London School of Economics, London

[56]. Srebstein J, Piazza T. Public Health Safety and educational risks associated with bullying behaviors in American adolescents. International Journal of Adolescent Medicine and Health 2008; 20(2): 223-233. 